\title{
MAP2K2 Gene Amplification
}

National Cancer Institute

\section{Source}

National Cancer Institute. MAP2K2 Gene Amplification. NCI Thesaurus. Code C153255.

A molecular genetic abnormality indicating the presence of multiple copies of the MAP2K2 gene. 